\title{
Nepalese malacology trails behind
}

\author{
"Catchup!"
}

\author{
Prem B Budha
}

I n terms of biological diversity, the Himalayan region is one of the world's richest ecosystems (Pei and Sharma 1998) and has been identified as a "biodiversity hotspot." Although Nepal constitutes only about $0.09 \%$ of the world's land area, it harbors a remarkable number of faunal species: $4.5 \%$ of all mammals, $9.5 \%$ of birds, $1.2 \%$ of amphibians, $2.03 \%$ of reptiles and $6.8 \%$ of butterflies and moths. China, which is 65 times greater in area than Nepal, is home to only $12.5 \%$ of the world's mammals, $6.3 \%$ of the birds, $9.1 \%$ of the amphibians and $18.8 \%$ of the reptiles. Similarly, India is 16 times greater than Nepal, but can claim only $8.6 \%$ of the mammals in the world, $13.3 \%$ of the birds, $4.3 \%$ of the amphibians and $7.2 \%$ of the reptiles (Pei 1996).

Unlike many other invertebrates, mollusks throughout most of the world are taxonomically a relatively well-known group. There are databases for Eastern Himalayan mollusks (covering Assam, Darjeeling, Arunachal, Meghalaya, and Burma) and also for Western Himalaya species (including those of Jammu, Kashmir, Himachal Pradesh and Gahrwal). No such database exists for mollusks of the Nepal Himalaya. Inadequate data and information management is considered a significant threat to Nepal's biodiversity conservation (MFSC 2002). Sporadic reports on the phylum from Nepal Himalaya are scattered in articles and dissertations throughout the world and not readily accessible to researchers; they have yet to be included in Nepal's biodiversity databases. Nonetheless, the existing databases reveal that the Himalayan region as a whole is rich in endemic mollusks: $94.6 \%$ of the terrestrial species and $47.8 \%$ of the freshwater species found in the eastern and central Himalayas are found only in the regions (Dey and Mitra 2000). Much taxonomic work remains to be done, particularly in Nepal, where we may expect to discover numerous endemic species of both terrestrial and freshwater mollusks, as well as new species, in the many unexplored and isolated microhabitats within the severely compressed
Mollusks of the world are, in general, more thoroughly documented than other invertebrates. This is the case for the Himalayas as well - except in Nepal. A scant 139 species have been reported from Nepal, but the new sightings reported every year and the high percentage of endemism (94.6 for terrestrial and $\mathbf{4 7 . 8}$ for aquatic mollusks) both suggest that a focused and accelerated study of these creatures is warranted. However, inauspicious externalities indicate that, for the foreseeable future, progress is unlikely to exceed the proverbial snail's pace.

bioclimatic zones (from tropical to nival) generated by the extreme altitudinal gradient (60 to 8848 masl in a country that is on average only $193 \mathrm{~km}$ wide). Without complete information on this important zoogeographic region, the world database of malacofauna remains woefully incomplete.

Taxonomic expertise is an indispensable foundation for estimation of global biodiversity and formulation of conservation policy (Golding and Timberlake 2002). The Seventh International Malacological Congress in 1980 recommended that governments, universities, museums and conservation agencies be urged to promote research on the taxonomy of mollusks (IUCN 1983). Article 7 of the Convention on Biological Diversity (CBD), which Nepal ratified in 1993, stipulates the importance of identification and monitoring of species and assemblages. Decision II/8 of the second meeting of the Conference of the Parties to the CBD identified the lack of taxonomists as a significant impediment to the implementation of the Convention at the national level. More recently, a workshop of the South Asian Loop of BioNet-International (SACNET) was held in Bangladesh (2003 June 15-20) in conjunction with the third regional session of the Global Biodiversity Forum (GBF) for South Asia; again, the participants emphasized the taxonomic impediment to implementation of the CBD for the whole region. Sadly, even two decades after the first wake-up call, taxonomic expertise on mollusk is shockingly poor in Nepal.

Taxonomic work in Nepal has proceeded at the proverbial mollusk's pace due to lack of advanced tools, trained staff, research infrastructure, logistic support and incentives for researchers. According to published resources, Pupilla eurina was the first mollusk reported from Nepal; Benson identified it as Pupa eurina in 1864 (Gude 1914). In 1909, more than four decades after the first report, Preston (1908) identified Limnaea (Gulnaria) simulans from a Nepalese specimen in the collection of the Indian Museum, Calcutta. Subba Rao (1989) details 285 species of freshwater mollusks collected in India, Pakistan, Bangladesh, Burma, Sri-Lanka and other adjoining countries. In Rao's handbook, the malacofauna of Nepal is represented by only two species Bellamya nepalensis and Lymnaea andersoniana. Recently, Dey and Mitra (2000) reviewed 689 species of freshwater and land mollusks found in the Himalayas; again, Nepal's mollusks are almost entirely absent, with only two species mentioned-L. andersoniana and Pupilla eurina. Scientists from other regions have carried out taxonomic research on mollusks during short expeditions to Nepal. They have identified many new taxa and their work indicates that Nepal is a promising area for further biodiversity and taxonomic research. In the literature survey, I found 139 species of mollusks (83 terrestrial and 56 freshwater) reported so far from Nepal, and new finds have been recorded every year. The discovery of two new genera of terrestrial mollusks: Ranibania (Schileyko and Kuznetsov 1996) and Nepaliena (Schileyko and Frank 1994), and eight new terrestrial species: Hemiphaedusa martensiana (Nordsieck 1973), H. kathmandica (Nordsieck 1973), Laevozevrinus nepalensis (Schileyko and Frank 1994), L. mustangensis (Kuznetsov and Schileyko 1997), Himalodiscus aculeatus (Kuznetsov 1996), Pupinidius tukuchensis (Kuznetsov and Schileyko $\Rightarrow$ 
1997), Anadenus nepalensis (Wiktor 2001) and Limax (Limax) seticus (Wiktor and Bössneck 2004) indicate that Nepal is rich in endemic terrestrial mollusk taxa. Nesemann and Sharma (2003) reported 45 species of aquatic mollusks (25 gastropods and 20 bivalves) from lowland (Terai) regions of Nepal; none of them are endemic. However, further study of freshwater mollusk taxonomy is required in order to more accurately assess Nepal's endowment. Recently several works have been undertaken to remedy the data deficiency of this important phylum (Subba and Ghosh 2001, Nesemann etal. 2001, Budha 2002, Nesemann and Sharma 2003 and Subba 2003).

Mollusks have significant economic value for the poor people and indigenous communities in Nepal and neighboring countries. Various freshwater bivalves and snails are used as a source of cheap animal protein, and the shells are used in traditional art. Lime produced from bivalve shells is mixed with chewing tobacco. Terrestrial slugs have been used in traditional treatments for body pain, fractured bones, and general health, as well as in dietary supplements to improve the yield of dairy cows (Budha 2002). Twenty ethnic groups in Bangladesh consume snail meat (Jahan and Rehaman 2000), and in India the shells are used in the manufacture of buttons, ornaments and lime. Four species of mollusks in Bihar and seven in Mizoram have been used by people as food (Subba Rao and Dey 1986). Shellfish are also useful in improving vision and in controlling diarrhea and gastric disorder (Suba Rao 1989). In addition, mollusks are also useful indicator for biological assessment of water quality monitoring (Nesemann and Sharma 2005, this issue paper, page 57$65)$. Some snails and slugs also act as intermediate hosts for parasites of domestic and wild animals. Lymnaeasp. is a causative agent for human schistosomiasis, and many countries have given high priority to its control (WHO 1993). Likewise, certain invasive land snails have also emerged as pests, causing substantial losses of vegetable crops in various regions of Nepal (Raut 1999). There are, however, no data available on specific shellfish-dependent ethnic groups, mollusk-harvesting practices, or impact on human health.

The systematic deposition of voucher specimens in scientific institutions and access to these collections can stimulate interest in taxonomy among young scientists. Such resources are lacking in Nepal. The primary institution for maintaining records of voucher specimens, the Natural History Museum in Swayambhu (Kathmandu), has no collection of Nepalese mollusks. Only 20 25 species of freshwater and land mollusks are represented in the museum of the Central Department of Zoology, Tribhuvan University in Kirtipur, and these have not been authoritatively identified or competently preserved. One auspicious development is the deposition of 56 authentically identified species of freshwater mollusks from Nepal at Kathmandu University (KU), Dhulikhel (Nesemann 2005, personal communication).

Clearly the need for a database on mollusk diversity within Nepal is urgent. To fill this information gap, I offer the following recommendations:

- The Natural History Museum and the universities of Nepal should undertake the proper deposition of voucher specimens of Nepalese malacofauna.

- Research institutes and conservation organizations should offer research opportunities for young taxonomists.

- The collection of baseline information on mollusks, including spatial diversity, distribution and ethnomalacology, should be established as a national research priority.

\section{Acknowledgements}

My sincere thanks go to J van Goethem, CBDNational Focal Point, Royal Belgian Institute of Natural Sciences (RBINS) for bibliographical assistance; and to Yves Samyn, RBINS and Peter Weekers, Ghent University (Belgium), for critiquing my initial manuscript.

\section{Prem B Budha is a lecturer at Central}

Department of Zoology, Tribhuvan University.

E-mail: prembudha@yahoo.com

\section{References}

Budha PB. 2002. Ecology of terrestrial slugs (Anadenus nepalensis Wiktor 2001) in Kathmandu valley. A report submitted to University Grant Commission, Kathmandu. $17 \mathrm{p}$

DeyAand SCMitra. 2000. Molluscs of the Himalaya. Records of the Zoological Survey of India $98(2)$ 5-50

Golding JS and J Timberlake. 2002. How taxonomists can bridge the gap between taxonomy and conservation science. Conservation Biology 17(4): 1177-1178

Gude GK. 1914. The fauna of British India including Ceylon and Burma. Mollusca III (Cyclophoridae, Truncatellidae, Assimineidae, Helicinidae). New Delhi: Today and Tomorrow's Printers and Publishers. 520 p

MFSC. 2002. Nepal biodiversity strategy. Ministry of Forests and Soil Conservation, HMGN Kathmandu, Nepal. $132 \mathrm{p}$

IUCN. 1983. The IUCN invertebrate red data book International Union for Conservation of Nature and Natural Resources. Unwin Brothers Limited, The Conservation Press, UK
Jahan MS and MR Rehaman. 2000. Prospects of snail culture in Bangladesh. In: Jha PK, SB Karmacharya, SR Baral and P Lacoul (eds), Environment and agriculture: At the crossroad of the new millennium. Kathmandu, Nepal: Ecological Society (ECOS). p 522-526

Kuznetsov AG. 1996. Himalodiscus aculeatus Kuznetsov, gen. et sp.nov. (Pulmonata, Endodontidae) from Nepal. Ruthenica 5(2): 163-165

Kuznetsov AG and AA Schileyko. 1997. New data on Enidae (Gastropoda, Pulmonata) of Nepal. Ruthenica 7(2): 133-140

MOPE. 2001. State of the environment, Nepal (Agriculture and Forestry). Kathmandu, Nepal: Ministry of Population and Environment, HMGN. $64 \mathrm{p}$

Nesemann H and S Sharma. 2003. Population dynamics and distribution of the aquatic Molluscs (Gastropods, Bivalvia) from Nepal. Paper presented at the International Conference on Himalayan Biodiversity, Kathmandu, Nepal; 2003 February 26-28

Nesemann H and S Sharma. 2005. Illustrated checklist of pea clams (Mollusca: Bivalvia: Sphaeriidae) from Nepal. Himalayan Journal of Sciences 3 (5): 57-65

Nesemann H, A Korniushin, S Khanal and S Sharma. 2001. Molluscs of the families Sphaeriidae and Corbiculidae (Bivalvia: Veneroidea) of Nepal (Himalayan midmountains and Terai), their anatomy and affinities. Acta Conchyliorum 4: 1-33

Nordsieck H. 1973. Zur Anatomie und Systematic der Clausilien XII. Phaedusinae: Phaedusen aus Nepal und ihre systematische Stellung innerhalb der Unterfamilie. Archiv fuer Molluskenkunde 103(1-3): 63-85

Pei Shengji (ed). 1996. Banking on biodiversity. A report of the regional consultation on biodiversity assessment in the Hindu Kush Himalayas. Kathmandu, Nepal: International Center for Integrated Mountain Development (ICIMOD)

Pei Shengji and UR Sharma. 1998. Transboundary biodiversity conservation in the Himalayas. In: Ecoregional co-operation for biodiversity conservation in the Himalaya. A report on the international meeting on Himalayan ecoregional cooperation organized by UNDP, WWF and ICIMOD; 199 Feb16-18; Kathmandu, Nepal

Preston HB. 1908. Description of new species of marine and freshwater shells, in the collection of the Indian museum, Calcutta. Records of the Indian Museum 2(1): 45-48

Raut SK. 1999. The Giant African land snail, Achatina fulica Bowdich in Nepal and Bhutan. Journal of the Bombay Natural History Society 96(1): 73

Schileyko AA and C Frank. 1994. Some terrestrial mollusca of the Nepalesian fauna. Archiv fuer Molluskenkunde 123 (1/6): 127-136

Schileyko AA and AG Kuznetsov. 1996. Anew genus of the Subulinidae (Pulmonata) from Nepal. Ruthenica 5(2): 158-160

Subba BR. 2003. Molluscan checklist of Ghodaghodi Tal area, Kailali district. Our Nature 1: 1-2

Subba BR and TKGhosh. 2001. Terrestrial Molluscs from Nepal. Journal of the Bombay Natural History Society 98(1): 58-61

Subba Rao NV and A Dey. 1986. Freshwater Molluscs of Mizoram. Journal of the Hydrobiology 2(3): 25-32

Subba Rao NV. 1989. Handbook: Freshwater Molluscs of India. Zoological Survey of India, Culcutta. 289 p

WHO. 1993. The control of schistosomiasis: Second report of WHO Expert Committee. WHO technical report series 830 . Geneva

Wiktor A. 2001. A review of Anadenidae (Gastropoda: Pulmonata) with a description of a new species. Folia Malacologia 9(1):3-26

Wiktor A. and U Bössneck. 2004. Limax (Limax) seticus $n$.sp. from high mountains in Nepal (Gastropoda: Pulmonata: Limacidae). Folia Malacologica 12(4): 183-187 